\title{
Chronic nitrogen fertilization and carbon sequestration in grassland soils: evidence of a microbial enzyme link
}

\author{
Valeria L. Cenini · Dario A. Fornara • \\ Geoffrey McMullan • Nigel Ternan • \\ Kate Lajtha $\cdot$ Michael J. Crawley
}

Received: 7 July 2015/Accepted: 31 October 2015/Published online: 14 November 2015

(C) The Author(s) 2015. This article is published with open access at Springerlink.com

\begin{abstract}
Chronic nitrogen (N) fertilization can greatly affect soil carbon $(\mathrm{C})$ sequestration by altering biochemical interactions between plant detritus and soil microbes. In lignin-rich forest soils, chronic $\mathrm{N}$ additions tend to increase soil $\mathrm{C}$ content partly by decreasing the activity of lignin-degrading enzymes. In cellulose-rich grassland soils it is not clear whether cellulose-degrading enzymes are also inhibited by $\mathrm{N}$ additions and what consequences this might have on changes in soil $\mathrm{C}$ content. Here we address whether chronic $\mathrm{N}$ fertilization has affected (1) the $\mathrm{C}$ content of light versus heavier soil fractions, and (2) the activity of four extracellular enzymes including the $\mathrm{C}$-acquiring enzyme $\beta$-1,4-glucosidase (BG; necessary for cellulose hydrolysis). We found that 19 years of
\end{abstract}

Responsible Editor: Sharon A. Billings.

Electronic supplementary material The online version of this article (doi:10.1007/s10533-015-0157-5) contains supplementary material, which is available to authorized users.

\section{L. Cenini}

Environmental Sciences Research Institute, University of Ulster, Coleraine BT52 1SA, UK

D. A. Fornara $(\bowtie)$

Agri-Food \& Biosciences Institute, Belfast BT9 5PX, UK

e-mail: dario.fornara@afbini.gov.uk

G. McMullan · N. Ternan

School of Biomedical Sciences, University of Ulster,

Coleraine BT52 1SA, UK chronic $\mathrm{N}$-only addition to permanent grassland have significantly increased soil $\mathrm{C}$ sequestration in heavy but not in light soil density fractions, and this $\mathrm{C}$ accrual was associated with a significant increase (and not decrease) of $\mathrm{BG}$ activity. Chronic $\mathrm{N}$ fertilization may increase BG activity because greater $\mathrm{N}$ availability reduces root $\mathrm{C}: \mathrm{N}$ ratios thus increasing microbial demand for $\mathrm{C}$, which is met by $\mathrm{C}$ inputs from enhanced root $\mathrm{C}$ pools in $\mathrm{N}$-only fertilized soils. However, $\mathrm{BG}$ activity and total root mass strongly decreased in high $\mathrm{pH}$ soils under the application of lime (i.e. $\mathrm{CaCO}_{3}$ ), which reduced the ability of these organo-mineral soils to gain more $\mathrm{C}$ per units of $\mathrm{N}$ added. Our study is the first to show a potential 'enzyme link' between (1) long-term additions of inorganic $\mathrm{N}$ to grassland soils, and (2) the greater $\mathrm{C}$ content of organo-mineral soil fractions. Our new hypothesis is that the 'enzyme link' occurs because (a) BG activity is stimulated by increased microbial $\mathrm{C}$ demand relative to $\mathrm{N}$ under chronic fertilization, and (b) increased BG activity causes more $\mathrm{C}$ from roots and from microbial

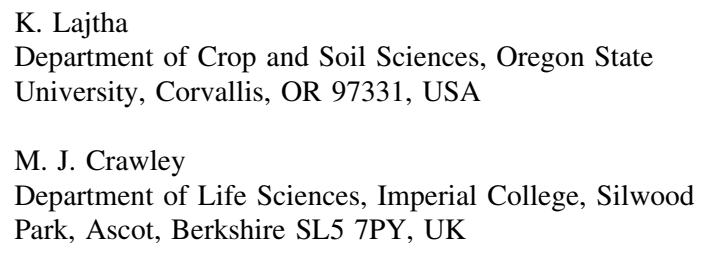


metabolites to accumulate and stabilize into organomineral $\mathrm{C}$ fractions. We suggest that any combination of management practices that can influence the BG 'enzyme link' will have far reaching implications for long-term $\mathrm{C}$ sequestration in grassland soils.

Keywords Extracellular enzyme activity $\cdot \beta-1,4-$ Glucosidase $\cdot$ Fertilization $\cdot$ Liming $\cdot$ Soil carbon sequestration $\cdot$ Root $\mathrm{C}: \mathrm{N}$ ratio

\section{Introduction}

The addition of inorganic nutrient fertilizers to grassland soils is a very common management practice, which greatly benefits the delivery of one important ecosystem service, namely plant biomass production. Chronic nutrient fertilization may, however, influence key regulatory services such as soil $\mathrm{C}$ sequestration, soil nutrient cycling, and greenhouse gas (GHG) emissions (Smith et al. 2013). Given the fact that grassland soils may store $30 \%$ of all terrestrial soil C (Scurlock and Hall 1998), have the potential to store more C than arable soils (Conant et al. 2001), and represent key life-support systems across different continents (FAO 2005), there is an urgent need to understand how long-term nutrient fertilization will affect the $\mathrm{C}$ sequestration ability of grassland soils.

Increasing evidence from forest ecosystems shows that $\mathrm{N}$ fertilization negatively influences the rate of lignin decomposition (Berg 1986; Berg and Matzner 1997; Magill and Aber 1998) by suppressing the production of lignin-degrading enzymes from white-rot Basidiomycetes and xylariacarious Ascomycetes (Keyser et al. 1978; Carreiro et al. 2000). This could result in a reduction in litter and soil organic matter decomposition (Berg et al. 1987; Fog 1988; Carreiro et al. 2000, Waldrop et al. 2004), and a decrease in the mineralization of old and humified organic matter (Hagedorn et al. 2003), which ultimately leads to greater soil $\mathrm{C}$ accumulation. In contrast, chronic $\mathrm{N}$ deposition tends to increase the activity of cellulose degrading enzymes (Ajwa et al. 1999; Carreiro et al. 2000; Saiya-Cork et al. 2002; Keeler et al. 2009) thus increasing the degradation of cellulose-rich litter (Fog 1988). Across forest ecosystems it is commonly accepted that the net effect of chronic $\mathrm{N}$-fertilization is the greater sequestration of $\mathrm{C}$ in soils mainly because of the increased accumulation of undecomposed organic matter detritus (Magill and Aber 1998).
In grassland ecosystems the net effect of chronic $\mathrm{N}$ fertilization on soil $\mathrm{C}$ sequestration is less clear, and findings from previous studies are contradictory. Recent studies show that $\mathrm{N}$ inputs can have positive effects on total soil C stocks (Fornara et al. 2013) and on the $\mathrm{C}$ content of both organic (Song et al. 2014) and mineral soils (Liu and Greaver 2010; Fornara and Tilman 2012). Other studies show that $\mathrm{N}$ fertilization has no effect on the $\mathrm{C}$ content of bulk soils (Zeglin et al. 2007) or on the $C$ content of organic and mineral soils (Lu et al. 2011). Such high soil $\mathrm{C}$ variability in response to $\mathrm{N}$ fertilization may depend on several environmental factors including differences in climate, soil and litter biochemical composition, management history, $\mathrm{N}$ addition rates and the time interval (years) to which soils have been exposed to chronic $\mathrm{N}$ additions; it may also depend on soil mineralogy and the reactivity of soil minerals (Sulman et al. 2014). Nevertheless, in order to clarify the cause of such high variability we need to improve our mechanistic understanding of (1) how chronic $\mathrm{N}$ fertilization ultimately affects the $\mathrm{C}$ content of free, or labile, organic matter pools versus stable-recalcitrant soil fractions (e.g., heavy organo-mineral fractions), and (2) how microbial activity, including the activity of cellulose-degrading enzymes, might respond to chronic $\mathrm{N}$ additions.

Here we address these two questions by using a long-term grassland experiment where soils have received different combinations of nutrient additions. We first ask whether 19 years of chronic nutrient additions have influenced the $\mathrm{C}$ content of light organic versus heavy organo-mineral fractions. If any $\mathrm{N}$-induced change in soil $\mathrm{C}$ content occurs in stable organo-mineral fractions, this could significantly influence the $\mathrm{C}$ sequestration ability of grassland soils. Second we ask whether chronic nutrient additions have influenced soil microbial function and extracellular enzyme activities. Extracellular enzymes play a key role in the decomposition of soil organic matter and in the release of $\mathrm{C}$ and nutrients in forms that can be either assimilated by microbes and plants or incorporated in soil fractions (Burns et al. 2013).

Our first hypothesis follows a simple economic framework for extracellular enzyme production, which suggests that microbial communities tend to allocate resources to enzyme production in relation to substrate availability and growth requirements 
(Chróst 1991; Sinsabaugh et al. 1993; Allison and Vitousek 2005). Thus we expect that the activities of $\mathrm{C}-$, N- or P-acquiring enzymes will increase or decrease as a response to the long-term conditioning effect that the addition of these nutrients would have had on soils within each experimental plot. For example we expect that the activity of an $\mathrm{N}$-acquiring enzyme (e.g., leucine aminopeptidase, LAP) would decrease in soils, which have received inorganic $\mathrm{N}$ inputs for 19 years. This is because it is energetically costly for the enzyme producers to synthetize LAP and acquire $\mathrm{N}$ from complex organic compounds in soils when inorganic (labile) forms of $\mathrm{N}$ are already available (Allison et al. 2011). On the other hand we would expect that the activity of a C-acquiring enzyme ( $\beta-1,4$ glucosidase, $B G)$, which is required for the hydrolysis of cellulose and other beta-linked glucans, would increase in grassland soils which have received inorganic $\mathrm{N}$ forms for 19 years. This is partly because cellulose degradation is often limited by $\mathrm{N}$ availability (Berg and Matzner 1997) but also because chronic $\mathrm{N}$ additions reduce the relative availability of $\mathrm{C}$ versus $\mathrm{N}$ for microbial energy demand thus increasing the need of microbes to acquire $\mathrm{C}$ by increasing $\mathrm{BG}$ activity to meet their 'intrinsic' C:N organismal stoichiometry (Sterner and Elser 2002).

Our second hypothesis is that in grassland ecosystems where soils receive low-lignified plant detritus and more cellulose-rich plant litter we expect that chronic $\mathrm{N}$-additions will ultimately lead to lower $\mathrm{C}$ sequestration because of $\mathrm{N}$-induced increases in (1) BG activity which contributes to $\mathrm{C}$ losses from the decomposition of organic detritus (e.g., from light soil fractions), and (2) the priming of stable soil organic matter associated with greater biological activity of microbes and roots which will reduce the $\mathrm{C}$ content of organo-mineral soils (i.e. heavy soil fractions; Lajtha et al. 2014). While priming has been observed in many forested soil systems, it is not clear whether and how the $\mathrm{C}$ content of stable heavy soil fractions in grasslands might respond to long-term $\mathrm{N}$ additions and increased root activity.

We tested our hypotheses in a long-term grassland experiment established at Silwood Park, London (UK), where soils have been conditioned with different combinations of nutrients $(\mathrm{N}, \mathrm{P}, \mathrm{K}, \mathrm{Mg}$ ) and also with inorganic $\mathrm{C}$ inputs through the application of agricultural lime (e.g., $\mathrm{CaCO}_{3}$ ) for 19 years.

\section{Methods}

Study site

Our study was carried out in the Nash's Field long-term grassland experiment established on acidic soils at Silwood Park, Berkshire, UK. Nash's Field is a sandy mesotrophic grassland described as Lolio-Cynosuretum cristati grassland, Anthoxanthum odoratum subcommunity according to the British National Vegetation Classification community (Rodwell 1992). Since 1947 Nash's Field had been used as a hay meadow (Crawley 1990). The long-term experiment was set up in summer 1991 for testing the effect of herbivory, insects, nutrient additions and liming and their interactions on plant community structure (Allan and Crawley 2011). Since 1991 the fenced plots (to exclude rabbits) were still managed as a hay meadow and in August each year the grass has been cut with a sickle bar mower for restraining the growth of woody plants. Soil sampling in 1991 indicated very low $\mathrm{P}$ values $\left(5.6 \pm 0.47 \mathrm{mg} \mathrm{kg}^{-1}\right.$ $\mathrm{NaHCO} 3$ soluble $\mathrm{P}$ ) as well as low Calcium (Ca) concentration $\left(638 \pm 34.3 \mathrm{mg} \mathrm{kg}^{-1}\right)$, associated with low soil $\mathrm{pH}(\mathrm{pH}=5.06 \pm 0.06)$. Values of exchangeable $\mathrm{K}$ and $\mathrm{Mg}$ were instead high $(88.4 \pm 7$ and $37.5 \pm 21 \mathrm{mg} \mathrm{kg}^{-1}$ respectively). Total atmospheric $\mathrm{N}$ deposition is estimated as $\sim 22 \mathrm{~kg} \mathrm{~N} \mathrm{ha}^{-1}$ year $^{-1}$ (www.apis.ac.uk). Nash's Field is a 4-factor factorial experiment, with a split-plot design where two of the four main plots (i.e. blocks), were allocated at random across the field and received insecticide whereas the other two did not $( \pm$ insects $)$. Each main plot $(22 \times 44 \mathrm{~m})$ was divided in half into subplots for the rabbit herbivory ( \pm grazing) and each of these subplots $(20 \times 20 \mathrm{~m})$ was then split into two soil $\mathrm{pH}$ treatments $\left( \pm\right.$ lime $\left.=\mathrm{CaCO}_{3}\right)$. Finally, liming and not liming sub-subplots $(18 \times 8 \mathrm{~m})$ were split into $5(2 \times 2 \mathrm{~m})$ plots each that received a combination of four fertilizer nutrients $(\mathrm{N}, \mathrm{P}, \mathrm{K}$ and $\mathrm{Mg}$ ) ( \pm nutrients); specifically, each year, from 1992 to 2011, mineral nutrients have been applied with the following concentrations: $100 \mathrm{~kg} \mathrm{ha}^{-1}$ of $\mathrm{N}$ (as ammonium nitrate), $35 \mathrm{~kg} \mathrm{ha}^{-1}$ of $\mathrm{P}$ (as triple superphosphate), $225 \mathrm{~kg} \mathrm{ha}^{-1}$ of $\mathrm{K}$ (as muriate of potash) and $11 \mathrm{~kg} \mathrm{ha}^{-1}$ of $\mathrm{Mg}$ (as Epsom salts). Each January, $5000 \mathrm{~kg}$ of $\mathrm{CaCO}_{3} \mathrm{ha}^{-1}$ were applied to the limed plots. A cocktail of insecticide was applied on three occasions each year since 1992 to the above-ground vegetation of -insect plots: chlorypyfos at $240 \mathrm{~g}$ active ingredient $\mathrm{ha}^{-1}$ and dimethoate-40 at $336 \mathrm{~g}$ active ingredient $\mathrm{ha}^{-1}$. We 
sampled plots, including all grazing, liming, and insect subplots, that received the following nutrient treatments: (1) N-only, (2) P-only, (3) N and P together, (4) simultaneous addition of all nutrients (N, P, K and Mg), and (5) no addition (control treatment). Thus 4 large plots $\times 2$ grazing treatments $( \pm$ grazing $) \times 2$ liming treatments $( \pm$ lime $) \times 5$ nutrient treatments $( \pm$ nutrients $)=80$ plots (each $2 \times 2 \mathrm{~m})$.

Soil and root sampling and analyses

After removing plant litter, soil samples were collected using a $3 \mathrm{~cm}$ diameter soil corer to a soil depth of $20 \mathrm{~cm}$ at four locations within each of the 80 experimental plots in July 2011. The samples were then sieved with a stainless 2-mm mesh to eliminate pebbles and roots; sub-samples were dried at $40{ }^{\circ} \mathrm{C}$ for 5 days, ground and analyzed for total $\mathrm{C}$ and $\mathrm{N}$ by combustion and gas chromatography (COSTECH Analytical ECS 4010 instrument). The ash of the soil samples furnace-burned for $16 \mathrm{~h}$ at $550{ }^{\circ} \mathrm{C}$ showed a negligible amount of inorganic $\mathrm{C}$. Two grams of the sieved soil sample was frozen for subsequent enzyme analyses.

Net soil $\mathrm{N}$ mineralization was measured in each plot. $20 \mathrm{~g}$ of sieved fresh soil were mechanically shaken for $0.5 \mathrm{~h}$ with $50 \mathrm{~mL}$ of a $1 \mathrm{~mol} / \mathrm{L}$ potassium chloride $(\mathrm{KCl})$ solution, kept overnight at $4{ }^{\circ} \mathrm{C}$, and analyzed for ammonium $\left(\mathrm{NH}_{4}{ }^{+}-\mathrm{N}\right)$ and nitrate $\left(\mathrm{NO}_{3}{ }^{-}-\mathrm{N}\right)$ with a Bran-Luebbe AA3 auto analyzer (Bran-Luebbe, Mequon, Wisconsin, USA). 80 soil subsamples were incubated in the dark for 30 days at $22{ }^{\circ} \mathrm{C}$ at constant moisture, and then analyzed for $\mathrm{NH}_{4}{ }^{+}-\mathrm{N}$ and $\mathrm{NO}_{3}{ }^{-}-\mathrm{N}$ as above. Net soil Nitrogen mineralization rates were calculated by subtracting initial extractable $\mathrm{NH}_{4}{ }^{+}-\mathrm{N}$ and $\mathrm{NO}_{3}{ }^{-}-\mathrm{N}$ concentrations per $\mathrm{g}$ of soil from final extractable $\mathrm{NH}_{4}{ }^{+}-\mathrm{N}$ and $\mathrm{NO}_{3}{ }^{-}-\mathrm{N}$ concentrations per $\mathrm{g}$ of soil. $10 \mathrm{~g}$ of fresh sieved soil was placed in aluminum trays, dried at $105{ }^{\circ} \mathrm{C}$ to a constant weight (minimum $48 \mathrm{~h}$ ), reweighed, to determine soil moisture content (\%). $10 \mathrm{~g}$ of fresh sieved soil was also dried and used for the determination of soil $\mathrm{pH}$ using a 1:5 (V/V) soil/ deionized water suspension. 80 soil sub-subsamples were collected in each plot, air-dried, ball milled to pass a $150 \mu \mathrm{m}$ sieve and then processed for the determination of total $\mathrm{P}$ with the sodium hydroxide $(\mathrm{NaOH})$ fusion method described by Smith and Bain (1982). Two additional soil samples per plot were taken to a depth of $20 \mathrm{~cm}$ using a PVC soil corer $8 \mathrm{~cm}$ in diameter to measure soil bulk density (calculated as the ratio between the mass of oven-dried soil and volume of fresh soil; $\left.\mathrm{g} / \mathrm{cm}^{3}\right)$. Four soil cores $(5 \mathrm{~cm}$ diameter) were collected in each plot to $20 \mathrm{~cm}$ depth to estimate total root mass. Soil samples were gently washed with water over a fine mesh screen until roots were free of soil. Roots were then dried $65^{\circ} \mathrm{C}$ to constant mass and weighed. Dry root material was analyzed for total $\mathrm{C}$ and $\mathrm{N}$ following standard methods on a 1500 NA Carlo-Erba element analyzer (Elan Tech., Lakewood, NJ, USA).

Finally, the percentage cover of all individual plant species in each small experimental plot $(2 \times 2 \mathrm{~m})$ was estimated (percentage cover was agreed by two investigators for each species) between July and August 2011. Plants were grouped into three functional groups: C3-grasses, legumes, and forbs.

\section{Soil fractionation}

Soils were fractionated into light (LF) and heavy (HF) density fraction pools using the methods of Crow et al. (2007). Air-dry soil was added to a $1.65 \mathrm{~g} \mathrm{~cm}^{-3}$ density solution of sodium polytungstate (SPT) $(1: 3$ soil to SPT ratio) and lightly shaken, after which the solution was adjusted to a final density of $1.65 \mathrm{~g} \mathrm{~cm}^{-3}$ to correct for dilution by moisture added by the soil. Soils were shaken for $1 \mathrm{~h}$ on a benchtop shaker and then separated into two fractions by aspirating the floating LF into a separate container. The sediment was subjected to the shaking ( $2 \mathrm{~min}$ ), separation, and aspiration steps twice more. The LF collected during the three separation cycles was combined; the remaining sediment constituted the HF. LF was rinsed thoroughly on pre-combusted Whatman GF/F filters. SPT was rinsed from the HF material by adding deionized water, shaking, and centrifuging for $15 \mathrm{~min}$ twice.

Enzyme analyses

We measured the potential activity of four hydrolytic enzymes (see Table 1) using a modified method of Saiya-Cork et al. (2002); $\beta$-1,4-glucosidase (BG) involved in cellulose degradation, $\beta-1,4-N$-acetyl-glucosaminidase (NAG) involved in chitin degradation, Lleucine aminopeptidase (LAP) required for the hydrolysis of leucine and other amino acid residues of peptides 
Table 1 Hydrolytic enzymes assayed in the soils collected from Nash's field (after 19 years of chronic nutrient additions) and their substrate

\begin{tabular}{|c|c|c|c|}
\hline Enzyme & EC & Substrate & Final Product \\
\hline $\begin{array}{l}\beta-1,4-\text { glucosidase (one of the cellulases } \\
\text { enzyme) (BG) }\end{array}$ & 3.2.1.21 & $\begin{array}{l}\text { 4-MUB- } \beta \text {-D } \\
\text { gluco(pyrano)side }\end{array}$ & $\begin{array}{l}\text { Glucose (sugar), important energy source } \\
\text { for microbes }\end{array}$ \\
\hline $\begin{array}{l}\beta-1,4-N \text {-acetyl-glucosaminidase (chitinase) } \\
\text { (NAG) }\end{array}$ & 3.2 .1 .14 & $\begin{array}{l}\text { 4-MUB- } N \text {-acetyl- } \beta \text {-D } \\
\text { glucosaminide }\end{array}$ & $N$-acetiyglucosamine (sugar) \\
\hline L-Leucine aminopeptidase (LAP) & 3.4.11.1 & $\begin{array}{l}\text { L-Leucine-7-amido-4 } \\
\text { methylcoumarin }\end{array}$ & Leucine and other amino acid residues \\
\hline Alkaline and acid phosphatase (AP) & $\begin{array}{l}3.1 .3 .1 \\
3.1 .3 .2\end{array}$ & 4-MUB-phosphate & Phosphate $\left(\mathrm{PO}_{4}\right)$ \\
\hline
\end{tabular}

$E C$ enzyme commission number, 4-MUB 4-methylumbelliferyl

and proteins and alkaline and acid phosphatase (AP) that hydrolyze bound organic phosphorus. Enzyme activity assays were performed using a $200 \mu \mathrm{M}$ solution of 4-methylumbelliferone- and coumarin-linked fluorogenic substrates and three biological buffers (acetate/maleate/bicarbonate) depending on the soil $\mathrm{pH}$; acetate buffer for acidic soil samples, maleate for mildlyacidic and neutral soils and bicarbonate for basic soils. The soil $\mathrm{pH}$ in the experiment ranged from values of 3.83 (non-limed soils) to 7.74 (limed soils). Soil suspensions (soil slurry) were prepared by adding two grams of soil to $250 \mathrm{~mL}$ of $50 \mathrm{mM}$ buffer and homogenizing for $4 \mathrm{~min}$ with a Silverston L4R homogenizer (Silverston Machines Ltd., England). The slurry was continuously mixed on a stir plate while $200 \mu \mathrm{l}$ aliquots were distributed onto a 96-well black microplate (Nunk $^{\circledR}$ FluoroNunc ${ }^{\mathrm{TM}}$ P8741 Sigma-Aldric) for preparing the blank, quench standard and assay wells. Blank wells also received $50 \mu \mathrm{l}$ of buffer, quench standard wells also received $50 \mu \mathrm{l}$ of standard solution $(10 \mu \mathrm{M}$ 4-methylumbelliferone-MUB-, or 7-amino-4-methylcoumarin-AMC- in the case of the LAP assay), and assay wells also received $50 \mu \mathrm{l}$ substrate solution. Reference standard wells received $200 \mu \mathrm{l}$ buffer plus $50 \mu \mathrm{l}$ of standard solution. Negative control (N) wells received $200 \mu$ lof buffer plus $50 \mu \mathrm{l}$ substrate solution. There were eight analytical replicate wells for each blank (buffer + slurry), negative control (buffer + substrate), reference standard (buffer + standard) and quench standard (slurry $+\mathrm{s}-$ tandard), and 16 analytical replicate wells for each sample assay (slurry + substrate). The final reaction volume for each well was $250 \mu \mathrm{l}$. The microplates were incubated in the dark at $20{ }^{\circ} \mathrm{C}$ for up to $24 \mathrm{~h}$. Fluorescence was measured without the previous addition of
$\mathrm{NaOH}$ (German et al. 2011; Shaw and DeForest 2013) using a FLUOstar Omega microplate reader (BMG Labtech) with $\lambda 365 \mathrm{~nm}$ excitation and $\lambda 460 \mathrm{~nm}$ emission filters. The product formation was measured at least 6 times between $0.5 \mathrm{~h}$ and $24 \mathrm{~h}$ after substrate addition. After converting the raw fluorescence data in enzyme activity units (nmol h${ }^{-1} \mathrm{~g}^{-1}=$ nanomoles of substrate transformed per hour per gram of soil) using the formula in German et al. (2011, 2012), the slope of the linear portion on a progress curve (product vs time) represented the enzyme activity for each soil sample (Shaw and DeForest, 2013).

Data analysis

The grassland experiment was conceived as a splitplot design where multiple factors are nested within each other. To test for the effects of these factors on changes in key plant, soil and microbial parameters we used a mixed effects ANOVA in which we considered the four large plots as random effects and the other treatment factors (insects, rabbit grazing, liming and nutrient addition treatments) as fixed effects. We tested these treatments effects on multiple response variables (i.e. soil $\mathrm{C}$, soil $\mathrm{N}$, extracellular enzyme activities, root mass, etc.). Since the pesticide and grazing treatments did not account significantly for variation in our key soil $\mathrm{C}$ and microbial variables, we then produced simpler models, which included only liming and 'nutrients' as fixed effects. We used restricted maximum likelihood (REML) methods to produce final models and checked that these models conformed to modeling assumptions. Significant differences between factor levels (i.e. five nutrient 
treatments) were tested using post hoc Tukey tests. We performed multiple regression analyses to address which belowground variables could significantly affect changes in the $\mathrm{C} \%$ content of the soil organomineral fraction. Linear regressions were used to test for the effects of different soil parameters (e.g., soil $\mathrm{pH}$ ) on enzyme activities. All analyses were conducted using JMP version 9.0 statistical software (SAS Institute Inc. 2010). We also calculated the difference in total soil $\mathrm{C}$ (and $\mathrm{N}$ ) pools between each nutrientfertilized plot and the average of the controls, and then divided this value by the cumulative amount of $\mathrm{N}$ added to that plot over 19 years. In this way we estimated the units of soil $\mathrm{C}$ gained per units of $\mathrm{N}$ added (i.e. "C gain efficiency" expressed as: $\mathrm{g} \mathrm{C} / \mathrm{g} \mathrm{N}$ added).

\section{Results}

$\mathrm{N}$-induced effects on soil carbon content

After 19 years of chronic nutrient fertilization we found that total soil $\mathrm{C}$ stocks (tonnes of $\mathrm{C}$ per hectare) were significantly higher $(\mathrm{P}=0.0006)$ under the N-only fertilization treatment (Supplementary Fig. 1). The $\mathrm{N}$-induced effect on soil $\mathrm{C}$ stocks seems to be driven by the accumulation of $\mathrm{C}$ in the heavy soil organo-mineral fraction $(\mathrm{P}<0.01)$ rather than in the light soil organic fraction (Fig. 1a, b). No significant pesticide or grazing effects were detected either on soil $\mathrm{C}(\%)$ content or on soil C stocks.

(a)

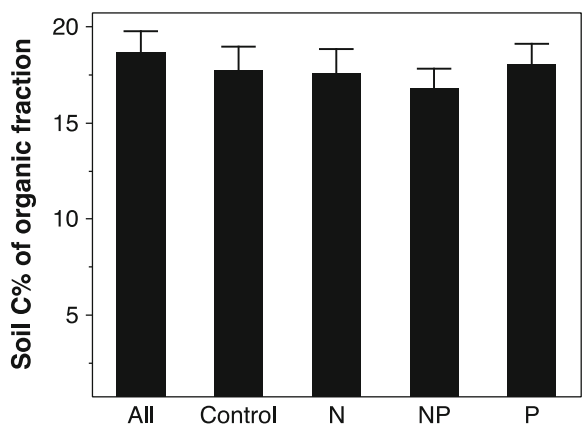

Fig. 1 Relationships between different nutrient treatments and the $\mathrm{C}(\%)$ content of light (organic) fractions (a), and heavier (organo-mineral) fractions (b) as separated by density
When we included soil $\mathrm{pH}$, root mass, root $\mathrm{C}: \mathrm{N}$ ratio and $\mathrm{BG}(\beta-1,4$-glucosidase) activity as independent variables we found that only BG activity was significantly positively related to soil $\mathrm{C} \%$ content of the organo-mineral fraction (Table 2). However BG activity was not significantly related to the $\mathrm{C} \%$ content of the light soil organic fraction (Table 2). Similarly we found that enzyme activities related to N acquisition (i.e. NAG and LAP) were significantly positively related to the $\mathrm{N} \%$ content of the heavy soil fraction but not significantly related to the $\mathrm{N} \%$ content of the light soil fraction (Supplementary Table 1). No significant grazing effects were detected on soil enzyme activities.

$\mathrm{N}$-induced effects on extracellular enzyme activity

We found that BG activity was significantly higher in grassland soils, which received chronic $\mathrm{N}$ additions (i.e. All, N-only and NP treatment plots; Supplementary Fig. 2). However, the positive $\mathrm{N}$-induced effect on BG activity was highly significant in non-limed soils ( $\mathrm{P}=0.008$; Fig. 2a) but was not significant in limed soils ( $\mathrm{P}=0.47$, Fig. $2 \mathrm{~b}$ ). In limed plots $\mathrm{N}$-only additions still contributed to increase $\mathrm{BG}$ activity (which was higher than under other experimental treatments) but this was not statistically significant. Moreover, we found that BG activity tends to decrease when $\mathrm{N}$ is added in combination with other nutrients (i.e. $\mathrm{P}$ or, $\mathrm{P}, \mathrm{K}$ and $\mathrm{Mg}$; Figs. 2a, b). We found evidence of negative liming-induced effects on AP (acid and alkaline phosphatase), and NAG ( $\beta-1,4-N$ -

(b)

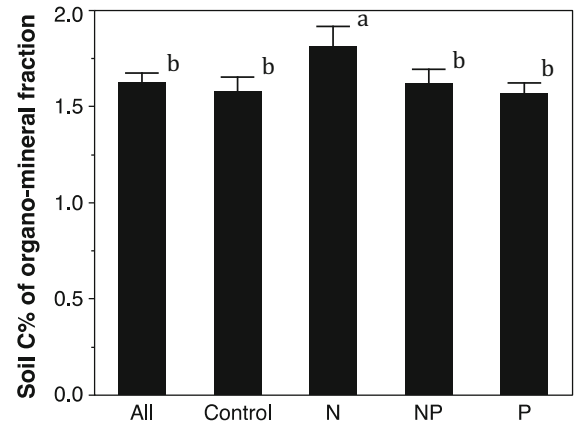

fractionation. Treatments not identified by same letter are significantly different (Tukey-Cramer HSD test). No significant differences shown in Fig. 1a 
Table 2 Results from multiple regression analyses showing that only the C (\%) content of soil organo-mineral (heavier) fractions are related to the activity of $\beta-1,4$ glucosidase (BG)

\begin{tabular}{|c|c|c|c|c|c|c|}
\hline \multirow[t]{2}{*}{ Independent variables } & \multicolumn{3}{|c|}{ Soil C \% of organic fraction (light fraction) } & \multicolumn{3}{|c|}{ Soil C $\%$ of organo-mineral fraction (heavy fraction) } \\
\hline & Estimate & t ratio & $\mathrm{P}$ & Estimate & t ratio & $\mathrm{P}$ \\
\hline Intercept & 10.7 & 1.23 & 0.22 & 0.34 & 0.54 & 0.59 \\
\hline $\operatorname{Ln}(\mathrm{BG})$ & 0.65 & 0.72 & 0.47 & 0.23 & 3.41 & 0.001 \\
\hline Soil pH & 1.18 & 1.44 & 0.15 & 0.11 & 1.89 & 0.06 \\
\hline Root mass $\left(\mathrm{g} / \mathrm{m}^{2}\right)$ & -0.005 & -1.52 & 0.13 & -0.0004 & -1.89 & 0.06 \\
\hline Root C:N & -0.06 & -0.70 & 0.48 & -0.007 & -1.27 & 0.21 \\
\hline
\end{tabular}

Bold indicates statistical significant values

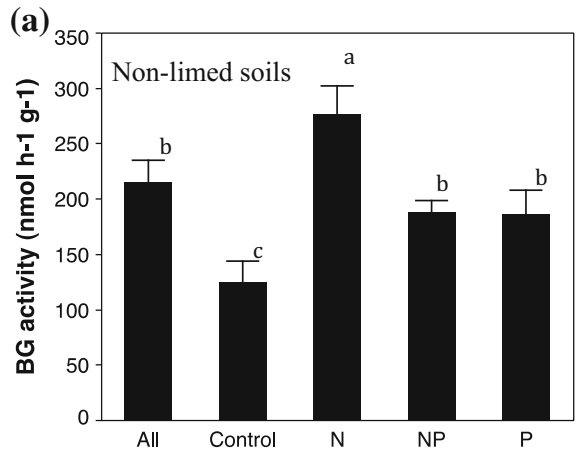

Fig. 2 Relationships between the activity of $\beta-1,4$ glucosidase (BG) $\left(\mathrm{nmol} \mathrm{h}^{-1} \mathrm{~g}^{-1}\right)$ and each of different nutrient addition treatments either in non-limed soils (a) or in soils receiving lime $\left(\mathrm{CaCO}_{3}\right)$ (b). Treatments not identified by same letter are

acetyl-glucosaminidase) activities and of strong positive liming effects on LAP (leucine aminopeptidase) activity (Fig. 3). The liming effect is partly explained by the positive effect of lime (i.e. $\mathrm{CaCO}_{3}$ ) applications on soil $\mathrm{pH}(\mathrm{P}<0.0001)$ which in turn was significantly negatively related $(\mathrm{P}<0.0001)$ to $\mathrm{AP}, \mathrm{BG}$, NAG activity and positively related to LAP activity. Overall we found a significant negative effect $(\mathrm{P}<0.001)$ of $\mathrm{N}$ fertilization (i.e. N-only, NP, All) on LAP activity.

The 'enzyme link' under nutrient and liming applications

We found that BG activity was positively related to the soil C (\%) content of the heavier organo-mineral soil fraction in both limed and unlimed soils (Fig. 4). BG activity was also significantly positively related $(\mathrm{P}=0.001)$ to the $\mathrm{C}$ gain efficiency of our grassland soils. However, among those soils, which received $\mathrm{N}$

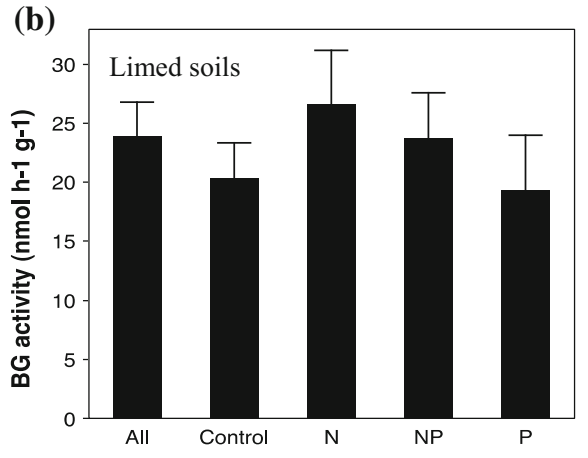

significantly different (Tukey-Cramer HSD test). Note the difference in scale of BG activity between limed and non-limed plots. No significant differences shown in Fig. 2b

fertilizer (i.e. All, N and NP), soil C gain efficiency was significantly higher under the $\mathrm{N}$-only treatment in non-limed plots (Fig. 5). This suggests a negative liming-induced effect on BG activity, which in turn has possibly reduced the ability of limed-soils to gain more $\mathrm{C}$ per units of $\mathrm{N}$ added. In fact the positive $\mathrm{N}$-only effect on soil $\mathrm{C}$ content of the heavier organomineral fraction was lower in limed plots (Supplementary Fig. 3). However limed soils under the $\mathrm{N}$-only treatment still show higher soil $\mathrm{C}(\%)$ of the organo-mineral fraction (although not significant) when compared to limed soils under different fertilization treatments (Supplementary Fig. 3).

Underlying mechanisms of the $\mathrm{N}$-induced effect on BG activity

Our analyses show that a potential mechanism through which $\mathrm{N}$ fertilization may contribute to increase $\mathrm{BG}$ activity is by determining changes in root chemistry 


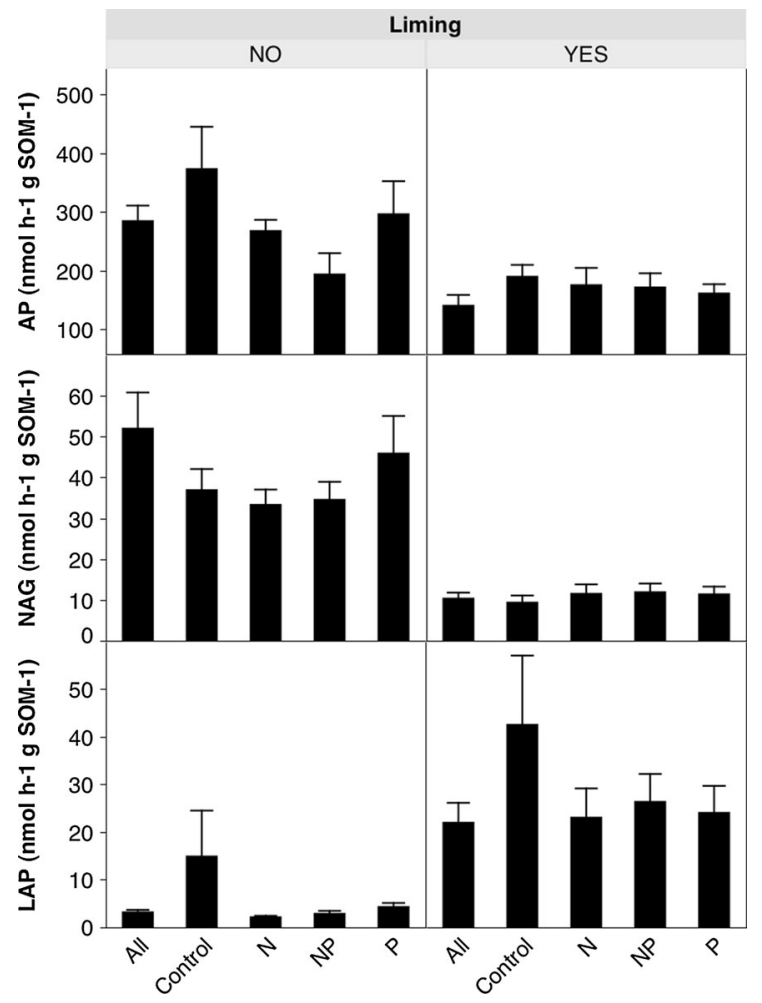

Fig. 3 Relationships between the activity of three different enzymes AP (alkaline and acid phosphatase), NAG ( $\beta-1,4-N$ acetyl-glucosaminidase) and LAP (L-leucine aminopeptidase) $\left(\mathrm{nmol} \mathrm{h}^{-1} \mathrm{~g} \mathrm{SOM}^{-1}\right)$ and each of different nutrient addition treatments either in non-limed soils or in soils receiving lime $\left(\mathrm{CaCO}_{3}\right)$

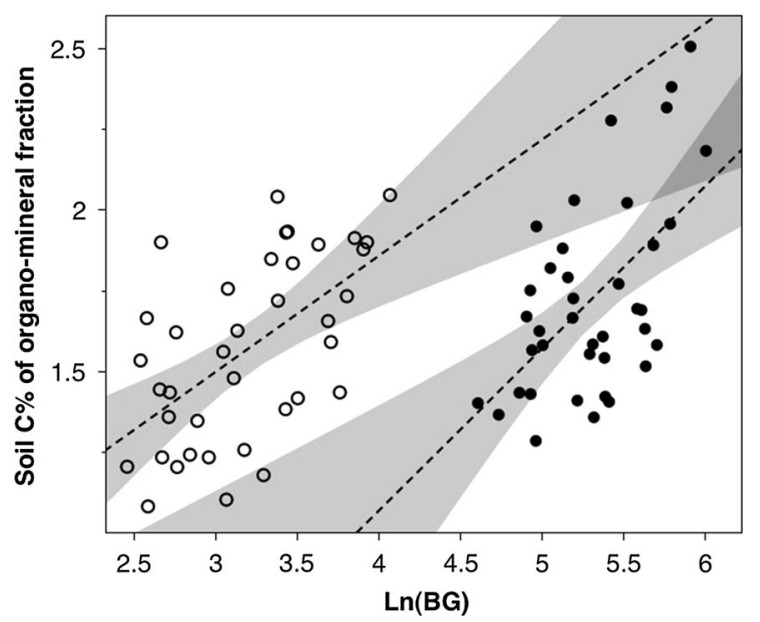

Fig. 4 Relationship between BG activity and the C (\%) content of the heavier organo-mineral soil fraction in both limed (open circles) and non-limed (close circles) plots. Regression fit for limed plots: $\left.\mathrm{y}=0.42+0.36 * \operatorname{Ln}(\mathrm{BG}) ; \mathrm{R}^{2}=0.33\right)$ and for non-limed plots $\left(\mathrm{y}=-0.94+0.5 * \operatorname{Ln}(\mathrm{BG}) ; \mathrm{R}^{2}=0.32\right)$

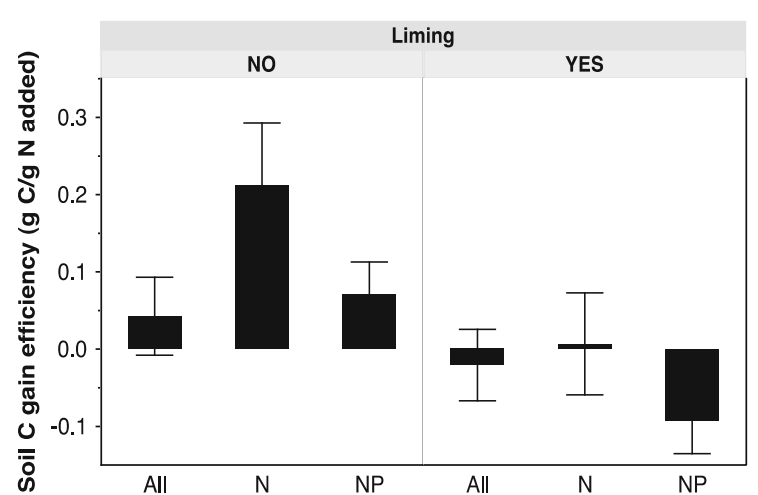

Fig. 5 Relationships between soil C gain efficiency (grams of $\mathrm{C}$ gained by soils per grams of $\mathrm{N}$ added over 19 years) and three different nutrient addition treatments either in non-limed soils or in soils receiving lime $\left(\mathrm{CaCO}_{3}\right)$

and total root mass. We found that in non-limed soils under the $\mathrm{N}$-only treatment root $\mathrm{C}: \mathrm{N}$ ratios were significantly lower $(\mathrm{P}=0.012$; Fig. $6 \mathrm{a})$ and total root mass was greater (although not significantly; Fig. 6b) when compared to other treatments. Changes in root $\mathrm{C}: \mathrm{N}$ ratios and root mass were not related to changes in plant functional groups (grasses, forbs, legumes). We found that $\mathrm{C} 3$ grasses remained dominant across the experimental plots regardless of nutrient and liming treatments (Supplementary Fig. 4).

Root $\mathrm{C}: \mathrm{N}$ ratios were significantly negatively related to BG activity (Fig. 7a), whereas BG activity was positively related to total root mass (Fig. 7b), which strongly differed between limed and non-limed soils. Our study shows that despite strong nutrient fertilization and liming effects on extracellular enzyme activities the relationship between organic $\mathrm{N}$-acquiring enzymes (NAG $+\mathrm{LAP}$ ) and $\mathrm{C}$-acquiring enzymes (BG) remained significant and positive across our grassland soils (Supplementary Fig. 5).

\section{Discussion}

Chronic $\mathrm{N}$ fertilization and enzyme activity

Overall our results show that chronic $\mathrm{N}$ fertilization (i.e. 19-years of $\mathrm{NH}_{4} \mathrm{NO}_{3}$-only additions) has contributed to increased $\mathrm{C}$ sequestration in grassland soils in spite of greater activity of the $\mathrm{C}$-acquiring enzyme $\beta$-1,4-glucosidase (BG). This confirms our first hypothesis that chronic $\mathrm{N}$ additions will result in higher BG activity, as was also found in previous 
grassland studies (Ajwa et al. 1999; Tiemann and Billings 2011) where BG activity significantly increased under $\mathrm{N}$-fertilization. This finding was
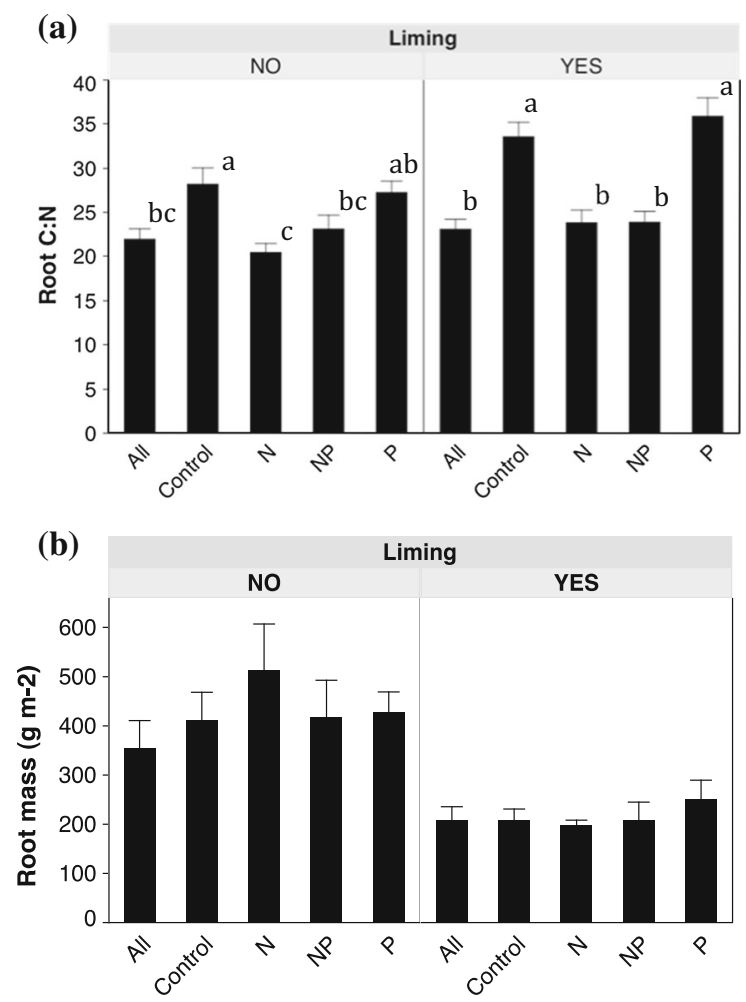

Fig. 6 Relationships between root C:N ratio (a) and root mass $\left(\mathrm{gm}^{-2}\right)(\mathbf{b})$ with different nutrient fertilization treatments in nonlimed and limed soils. Nutrient treatments not identified by same letter are significantly different (Tukey-Cramer HSD test). No significant differences among nutrient treatments on root mass in Fig. $6 b$

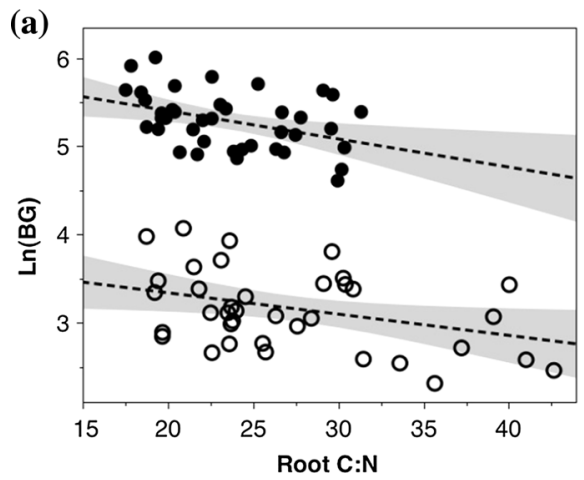

Fig. 7 Dependence of $\beta$-glucosidase activity $\left(\mathrm{nmol} \mathrm{h}^{-1} \mathrm{~g}^{-1}\right)$ on a root $\mathrm{C}: \mathrm{N}$ ratios, and $\mathbf{b}$ total root mass $\left(\mathrm{g} \mathrm{m}^{-2}\right)$. Relationships between root mass and nutrients treatments either in non-limed soils or in soils receiving lime $\left(\mathrm{CaCO}_{3}\right)$. Open circles (limed explained in Ajwa et al. (1999) by the fact that $\mathrm{N}$-fertilized soils, by supporting greater plant growth, also support a greater variety and biomass of microorganisms able to produce BG. The positive plant growth-related effect on BG activity may well occur in our grassland experiment where plant biomass production is significantly higher in $\mathrm{N}$-fertilized plots (i.e. either NP, All or N-only treatments) compared to non$\mathrm{N}$ fertilized or control plots (Fornara et al. 2013). However, our results show that BG activity is particularly high in the N-only fertilized (non-limed) plots, which indicates that other mechanisms may play a significant role. In particular our results suggest that the positive relationship between BG activity and the $\mathrm{C}(\%)$ content of organo-mineral soils may depend on the relative availability of $\mathrm{C}$ versus $\mathrm{N}$ for microbial energy demand.

Soil enzyme production tends to be controlled by the relative quantity of resources that organisms need to acquire (Allison et al. 2011) according to their 'intrinsic' organismal stoichiometry (Sterner and Elser 2002). Thus we would expect that 19 years of N-only additions would have contributed to increase microbial $\mathrm{C}$ demand (compared to $\mathrm{N}$ demand) by reducing the $\mathrm{C}: \mathrm{N}$ ratio of plant material returned to the soil. Our results show indeed that root $\mathrm{C}: \mathrm{N}$ ratios are particularly low in the N-only fertilized plots (Fig. 6a) and that $\mathrm{BG}$ activity is negatively related to root $\mathrm{C}: \mathrm{N}$ ratios across both limed and non-limed soils (Fig. 7a). These results agree with previous findings (Tiemann and Billings 2011), which show greater BG activity associated with $\mathrm{N}$-induced increases in plant substrate

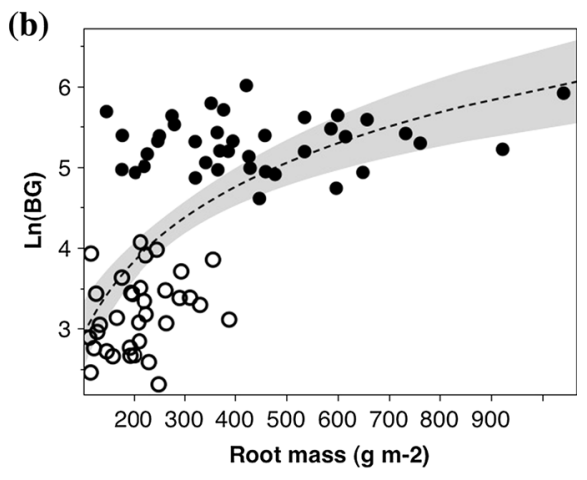

soils), black-filled circles (non-limed soils). Linear fit: $\mathrm{y}=6.04$ $-0.03 *$ Root C:N (non-limed soils), y $=3.8-0.02 *$ Root C:N (limed soils). $\log$ fit: $\mathrm{y}=-3.2+1.32 * \operatorname{Ln}($ Root mass) 
quality (i.e. low plant $\mathrm{C}: \mathrm{N}$ ratios). Positive $\mathrm{N}$ addition effects on cellulose-degrading enzymes were also found in forest (Carreiro et al. 2000; Saiya-Cork et al. 2002; Allison et al. 2008; Keeler et al. 2009; Cusak et al. 2011) and grassland studies (Ajwa et al. 1999; Stursova et al. 2006; Keeler et al. 2009). Other studies, however, found that $\mathrm{N}$ addition can have variable effects on BG activity along a soil age gradient (Zeglin et al. 2007) or that $\mathrm{N}$ fertilization does not have any significant effect on BG activity (Mineau et al. 2014).

Further research could address whether and how these variable effects of $\mathrm{N}$ fertilization on $\mathrm{BG}$ activity may depend on the spatial scale considered (i.e. plot vs. landscape) and across gradients of soil age, soil pH and fertility and changes in plant stoichiometry (e.g., root $\mathrm{C}: \mathrm{N}$ ratios). For example, in our study increases in soil $\mathrm{pH}$ following liming applications could be responsible for the observed decrease in BG activity, which in turn was associated with lower $\mathrm{C}$ gain efficiency of limed-soils (Fig. 5). Changes in soil pH may have indirect effects on BG activity either by influencing its temperature sensitivity or by influencing the $\mathrm{C}: \mathrm{N}$ flow ratio (from decomposing organic substrate) which becomes available for microbial assimilation (Min et al. 2014). In our study it is possible that increases in root $\mathrm{C}: \mathrm{N}$ ratios associated with liming (under the $\mathrm{N}$-only fertilization treatment) may have contributed to increases in $\mathrm{C}$ availability thus promoting declines in microbial $\mathrm{C}$ use efficiency which ultimately reduced soil $\mathrm{C}$ gain efficiency per unit of $\mathrm{N}$ added to limed plots. Reduced microbial $\mathrm{C}$ use efficiency in limed soils was also found in a longterm grassland experiment where high soil $\mathrm{pH}$ was associated with (1) a higher temperature sensitivity of soil respiration, (2) greater soil respiration rates, and (3) higher microbial metabolic quotients (Fornara et al. 2011). If this suggests less efficient microbial utilization of $\mathrm{C}$ in limed soils (microbes respiring more $\mathrm{C}$ per unit of degradable $\mathrm{C}$ ), it does not mean that limed soils have overall low $\mathrm{C}$ content, in fact soil $\mathrm{C}$ (\%) could be higher in soils receiving long-term lime applications (Fornara et al. 2011).

Our findings in relation to changes in enzyme activities also agree with economic theories of microbial metabolism, which suggest that enzyme production is regulated by the relative abundance of simple versus complex C-, N-, P-related organic compounds (Allison and Vitousek 2005; Sinsabaugh and Follstad Shah 2012). This is supported in our study by similar responses that other enzymes showed to increased nutrient availability. For example chronic $\mathrm{N}$ additions (compared to control plots) contributed to decrease the activity of leucine aminopeptidase (LAP), which hydrolyzes peptide bonds associated with common protein amino acids (leucine and alanine; Fig. 3). On the contrary LAP activity was significantly higher under liming applications. The importance of the enzyme link in influencing changes in soil $\mathrm{C}$ (and $\mathrm{N}$ ) accumulation may depend on the extent to which $\mathrm{N}$ (and C) inputs will affect microbial energy demand through the alteration of soil $\mathrm{N}$ availability and plant $\mathrm{C}: \mathrm{N}$ stoichiometry.

The "enzyme link" and $\mathrm{C}$ sequestration in $\mathrm{N}$ fertilized grassland soils

Contrary to our second hypothesis we found that BG activity was significantly positively related to greater $\mathrm{C}$ content of organo-mineral soils. It is not clear however how BG is linked to changes in soil $\mathrm{C}$ content. The increased activity of $\mathrm{C}$-acquiring enzymes such as BG should be related to higher $\mathrm{C}$ losses (and not $\mathrm{C}$ gains) from soils due to potential increases in both soil decomposition and respiration rates (Allison et al. 2010). It could be that $\mathrm{C}$ accrual in our grassland soils partly results from the $\mathrm{N}$-induced suppression of heterotrophic respiration (Janssens et al. 2010; Lu et al. 2011) and the inhibition of some extracellular enzyme activities (Ramirez et al. 2012), including the activity of lignin-degrading enzymes as has been observed in forest ecosystems. Grandy et al. (2008) found that although chronic $\mathrm{N}$ deposition can stimulate BG activity it could also increase the ratio of lignin derivatives to polysaccharides, which is ultimately related to $\mathrm{C}$ accrual in forest soils.

Another possibility is that chronic $\mathrm{N}$-only additions, by increasing total root mass (Fornara and Tilman 2012; this study) and by influencing microbial-mediated transformations of fine root detritus (Thomas et al. 2012), ultimately increase root $C$ stabilization in soils. In our study $\mathrm{N}$-only fertilization was associated with increases in total root mass at least in the non-limed plots (Fig. 6b), and because roots are responsible for substantial C contributions to mineral soils (Trumbore and Gaudinski 2003; Rasse et al. 2005), this could partly explain soil $\mathrm{C}$ accrual in our $\mathrm{N}$-only fertilized plots. However, if increased root mass alone was the causal agent for the observed increase in total soil C, we 
would have expected to see increases in the $\mathrm{C}$ content of the light soil fraction rather than increases in the $\mathrm{C}$ content of the heavy soil fractions. The $\mathrm{C}$ accrual in heavy fractions supports the idea that this $\mathrm{C}$ represents microbially-transformed inputs of $\mathrm{C}$ to soils. We thus found no evidence of priming of soil $\mathrm{C}$ from heavy fractions by labile $\mathrm{C}$ inputs in our grassland system.

Here we propose the hypothesis that chronic $\mathrm{N}$ fertilization and greater $\mathrm{C}$ accumulation in soil organo-mineral fractions (i.e. heavier soil fractions) are 'linked' by increases in BG activity (Fig. 8). First, we suggest that long-term additions of $\mathrm{N}$ to soils contribute to reduce the $\mathrm{C}: \mathrm{N}$ ratio of plant material (including roots) returned to the soil, thus increasing microbial energy demand for C. Second, increased C demand by microbes is met by increases in $\mathrm{BG}$ activity which is supported by $\mathrm{C}$ inputs from roots (including $\mathrm{C}$ compounds from root exudates). Finally, increased $\mathrm{BG}$ activity is associated with greater production of microbially-transformed $\mathrm{C}$ inputs which accumulate, and stabilize, in organo-mineral heavy soil fractions.

Our hypothesis agrees with the recently proposed Microbial Efficiency-Matrix Stabilization (MEMS) framework which explicitly suggests that labile plant inputs to soils (e.g., plant detritus with low $\mathrm{C}: \mathrm{N}$ ratio) represent dominant sources of microbial products mainly because this plant material is utilized more efficiently by microbes (Cotrufo et al. 2013). Based on MEMS we could expect that the presence of substrates rich in $\mathrm{N}$ (as in our long-term $\mathrm{N}$-fertilized soils) may lead to increases in both microbial biomass and products. It is possible that increased biological activity in our soils would lead to greater production of microbial metabolites, which bind to minerals to build organo-mineral soil fractions. This would explain why we found a positive relationship between $\mathrm{N}$ fertilization, $\mathrm{BG}$ activity and the $\mathrm{C}$ content of organo-mineral fractions. This also agrees with the findings from a long-term $\mathrm{N}$ fertilization experiment in meadow communities of alpine tundra, which suggest that under chronic $\mathrm{N}$ addition detritus plant material can move directly into stabilized mineral-associated organic matter pools (Neff et al. 2002). Finally, our finding agrees with the observation that $\mathrm{N}$ fertilization can contribute to $\mathrm{C}$ accumulation and stabilization in small mineral-associated soil aggregates (Riggs et al. 2015).

Our study is the first to show a potential 'enzyme link' between long-term additions of inorganic $\mathrm{N}$ to

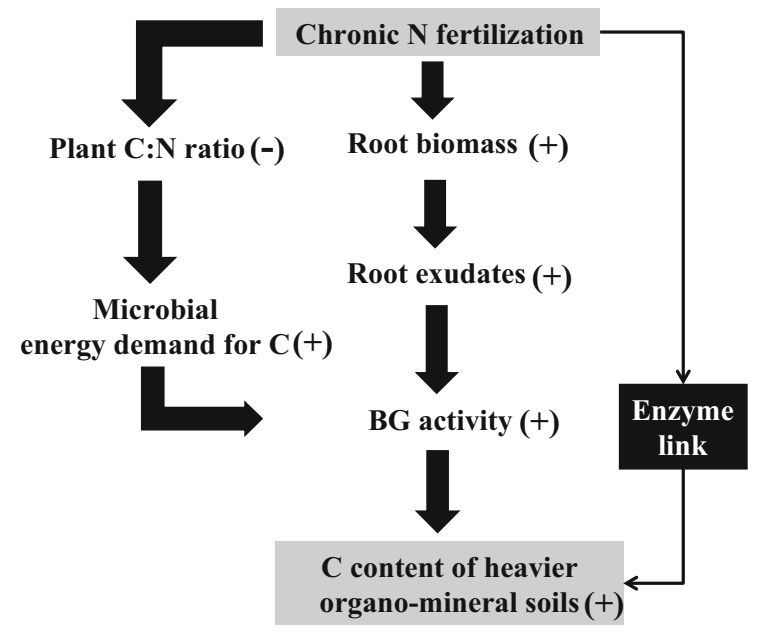

Fig. 8 Conceptual diagram showing the potential 'enzyme link' between chronic $\mathrm{N}$ fertilization and greater $\mathrm{C}$ content of heavy soil organo-mineral fractions. The enzyme link occurs because (1) chronic $\mathrm{N}$ fertilization contributes to reduce root $\mathrm{C}: \mathrm{N}$ ratios and increase microbial $\mathrm{C}$ demand, (2) increased BG activity is supported by positive $\mathrm{N}$-induced effects on $\mathrm{C}$ inputs from root mass (and root exudates), (3) increased BG activity contributes to process more $\mathrm{C}$ (from roots) part of which accumulates and stabilizes in heavier soil organo-mineral fractions

grassland soils and the greater $\mathrm{C}$ content of organomineral soil fractions. We suggest that the enzyme link occurs because BG activity is stimulated by increased microbial $\mathrm{C}$ demand relative to $\mathrm{N}$ under chronic fertilization and because increased BG activity causes more $\mathrm{C}$ from roots and from microbial metabolites to accumulate and stabilize in organo-mineral $\mathrm{C}$ fractions. The enzyme link is less significant in (1) limed soils possibly because of liming-induced increases in soil $\mathrm{pH}$ and decreases in root mass, and (2) in soils receiving multiple nutrients (i.e. NPK) possibly because of decreases in total root mass. Further studies could address what other potential biogeochemical mechanisms could explain the potential effect of different combination of common agricultural practices (e.g., liming and multi-nutrient additions) on soil $\mathrm{C}$ sequestration in human-managed grasslands.

Open Access This article is distributed under the terms of the Creative Commons Attribution 4.0 International License (http:// creativecommons.org/licenses/by/4.0/), which permits unrestricted use, distribution, and reproduction in any medium, provided you give appropriate credit to the original author(s) and the source, provide a link to the Creative Commons license, and indicate if changes were made. 


\section{References}

Ajwa HA, Dell CJ, Rice CW (1999) Changes in enzyme activities and microbial biomass of tallgrass prairie soil as related to burning and nitrogen fertilization. Soil Biol Biochem 31:769-777. doi:10.1016/S0038-0717(98)00177-1

Allan E, Crawley MJ (2011) Contrasting effects of insect and molluscan herbivores on plant diversity in a long-term field experiment. Ecol Lett 14:1246-1253. doi:10.1111/j.14610248.2011.01694.x

Allison SD, Vitousek PM (2005) Responses of extracellular enzymes to simple and complex nutrient inputs. Soil Biol Biochem 37:937-944. doi:10.1016/j.soilbio.2004.09.014

Allison SD, Czimczik CI, Treseder KK (2008) Microbial activity and soil respiration under nitrogen addition in Alaskan boreal forest. Glob Change Biol 14:1156-1168. doi:10.1111/j.1365-2486.2008.01549.x

Allison SD, Gartner TB, Mack MC, McGuire K, Treseder K (2010) Nitrogen alters carbon dynamics during early succession in boreal forest. Soil Biol Biochem 42:1157-1164. doi:10.1016/j.soilbio.2010.03.026

Allison SD, Weintraub MN, Gartner TB, Waldrop MP (2011) Evolutionary-economic principles as regulators of soil enzyme production and ecosystem function. In: Shukla G, Varma A (eds) Soil enzymology, 1st edn. Springer, Berlin, pp 229-243. doi:10.1007/978-3-642-14225-3

Berg B (1986) Nutrient release from litter and humus in coniferous forest soils - A mini review. Scand J For Res 1:359-369. doi:10.1080/02827588609382428

Berg B, Matzner E (1997) Effect of N deposition on decomposition of plant litter and soil organic matter in forest systems. Environ Rev 5:1-25. doi:10.1139/a96-017

Berg B, Staaf H, Wessen B (1987) Decomposition and nutrient release in needle litter from nitrogen-fertilized scots pine (pinus sylvestris) stands. Scand J For Res 2:399-415. doi: $10.1080 / 02827588709382478$

Burns RG, DeForest JL, Marxsen J, Sinsabaugh RL, Stromberger ME, Wallenstein MD, Weintraub MN, Zoppini A (2013) Soil enzymes in a changing environment: current knowledge and future directions. Soil Biol Biochem 58:216-234. doi:10.1016/j.soilbio.2012.11.009

Carreiro MM, Sinsabaugh RL, Repert DA, Parkhurst DF (2000) Microbial enzyme shifts explain litter decay responses. Ecol 81:2359-2365. doi:10.1890/0012-9658(2000)081 [2359:MESELD]2.0.CO;2

Chróst RJ (1991). Environmental control of the synthesis and activity of aquatic microbial ectoenzymes. In: Chróst RJ (ed) Microbial enzymes in aquatic environments, 1st edn. Springer, New York, 25-59. doi:10.1007/978-1-46123090-8

Conant RT, Paustian K, Elliott ET (2001) Grassland management and conversion into grassland: effects on soil carbon. Ecol Appl 11:343-355. doi:10.1890/1051-0761(2001)011 [0343:GMACIG]2.0.CO;2

Cotrufo MF, Wallenstein M, Boot CM, Denef K, Paul E (2013) The microbial efficiency-matrix stabilization (MEMS) framework integrates plant litter decomposition with soil organic matter stabilization: do labile plant inputs form stable soil organic matter? Glob Change Biol 19:988-995. doi: $10.1111 /$ gcb. 12113
Crawley MJ (1990) Rabbit grazing, plant competition and seedling recruitment in acid grassland. J Appl Ecol 27:803-820. doi:10.2307/2404378

Crow SE, Swanston CW, Lajtha K, Brooks JR, Keirstead H (2007) Density fractionation of forest soils: methodological questions and interpretation of incubation results and turnover time in an ecosystem context. Biogeochemistry 85:69-90. doi:10.1007/s10533-007-9100-8

Cusak DF, Silver WL, Torn MS, Burton SD, Firestone MK (2011) Changes in microbial community characteristics and soil organic matter with nitrogen additions in two tropical forests. Ecology 92:621-632. doi:10.1890/100459.1

FAO (2005) Grasslands of the world. In: Suttie JM, Reynolds SG, Batello C (eds) Plant Production and Protection Series No. 34. FAO, Rome

Fog K (1988) The effect of added nitrogen on the rate of decomposition of organic matter. Biol Rev 63:433-462. doi:10.1111/j.1469-185X.1988.tb00725.x

Fornara DA, Tilman D (2012) Soil carbon sequestration in prairie grasslands increased by chronic nitrogen addition. Ecol 93:2030-2036. doi:10.1890/12-0292.1

Fornara DA, Steinbeiss S, McNamara NP, Gleixner G, Oakley S, Poulton PR, Macdonald AJ, Bardgett RD (2011) Increases in soil organic carbon sequestration can reduce the global warming potential of long-term liming to permanent grassland. Glob Chan Biol 17:1925-1934. doi:10. 1111/j.1365-2486.2010.02328.x

Fornara DA, Banin L, Crawley MJ (2013) Multi-nutrient vs. nitrogen-only effects on carbon sequestration in grassland soils. Glob Chan Biol 19:3848-3857. doi:10.1111/gcb. 12323

German DP, Weintraub MN, Grandy AS, Lauber CL, Rinkes ZL, Allison SD (2011) Optimization of hydrolytic and oxidative enzyme methods for ecosystem studies. Soil Biol Biochem 43:1387-1397. doi:10.1016/j.soilbio.2011.03.017

German DP, Weintraub MN, Grandy AS, Lauber CL, Rinkes ZL, Allison SD (2012) Corrigendum to "Optimization of hydrolytic and oxidative enzyme methods for ecosystem studies" [Soil Biol Biochem 43 (2011) 1387-1397]. Soil Biol Biochem 44:151. doi:10.1016/j.soilbio.2011.11.002

Grandy AS, Sinsabaugh RL, Neff JC, Stursova M, Zak DR (2008) Nitrogen deposition effects on soil organic matter chemistry are linked to variation in enzymes, ecosystems and size fractions. Biogeochemistry 91:37-49. doi:10. 1007/s10533-008-9257-9

Hagedorn F, Spinnler D, Siegwolf R (2003) Increased N deposition retards mineralization of old organic matter. Soil Biol Biochem 35:1683-1692. doi:10.1016/j.soilbio.2003. 08.015

Janssens IA, Dieleman W, Luyssaert S, Subke J-A, Reichstein M, Ceulemans R, Ciais P, Dolman AJ, Grace J, Matteucci G, Papale D, Piao SL, Schulze E-D, Tang J, Law BE (2010) Reduction of forest soil respiration in response to nitrogen deposition. Nat Geosci 3:315-322. doi:10.1038/ngeo844

Keeler BL, Hobbie SE, Kellogg LE (2009) Effects of long-term nitrogen addition on microbial enzyme activity in eight forested and grasslands sites: implications for litter and soil organic matter decomposition. Ecosyst 12:1-15. doi:10. 1007/s10021-008-9199-z 
Keyser P, Kirk TK, Zeikus JG (1978) Ligninolytic enzyme of Phanerochaete chrysosporium: synthesized in the absence of lignin in response to nitrogen starvation. J Bacteriol 135:790-797

Lajtha K, Bowden RD, Nadelhoffer K (2014) Litter and root manipulations provide insights into soil organic matter dynamics and stability. Soil Sci Soc Am J 78:S261-S269. doi:10.2136/sssaj2013.08.0370nafsc

Liu L, Greaver TL (2010) A global perspective on belowground carbon dynamics under nitrogen enrichment. Ecol Lett 13:819-828. doi:10.1111/j.1461-0248.2010.01482.X

Lu M, Zhou X, Luo Y, Yang Y, Fang C, Chen J, Li B (2011) Minor stimulation of soil carbon storage by nitrogen addition: a meta-analysis. Agric Ecosyst Environ 140:234-244. doi:10.1016/j.agee.2010.12.010

Magill AH, Aber JD (1998) Long-term effects of experimental nitrogen additions on foliar litter decay and humus formation in forest ecosystems. Plant Soil 203:301-311. doi:10.1023/A:1004367000041

Min K, Lehmeier CA, Ballantyne F, Tatarko A, Billings SA (2014) Differential effects of $\mathrm{pH}$ on temperature sensitivity of organic carbon and nitrogen decay. Soil Biol Biochem 76:193-200. doi:10.1016/j.soilbio.2014.05.021

Mineau MM, Fatemi FR, Fernandez IJ, Simon KS (2014) Microbial enzyme activity at the watershed scale: response to chronic nitrogen deposition and acute phosphorus enrichment. Biogeochemistry 117:131-142. doi:10.1007/ s10533-013-9869-6

Neff JC, Townsend AR, Gleixner G, Lehman SJ, Turnbull J, Bowman WD (2002) Variable effects of nitrogen additions on the stability and turnover of soil carbon. Nature 419:915-917. doi:10.1038/nature01136

Ramirez KS, Craine JM, Fierer N (2012) Consistent effects of nitrogen amendments on soil microbial communities and processes across biomes. Glob Change Biol 18:1918-1927. doi:10.1111/j.1365-2486.2012.02639.x

Rasse DP, Rumpel C, Dignac MF (2005) Is soil carbon mostly root carbon? Mechanisms for a specific stabilisation. Plant Soil 269:341-356. doi:10.1007/s11104-004-0907-y

Riggs CE, Hobbie SE, Bach EM, Hofmockel KS, Kazanski CE (2015) Nitrogen addition changes grassland soil organic matter decomposition. Biogeochemistry 125:203-219. doi:10.1007/s10533-015-0123-2

Rodwell JS (1992) British plant communities. In: Rodwell JS (ed) Grassland and montane communities, vol 3, 1st edn. Cambridge University Press, Cambridge, pp 60-67

Saiya-Cork KR, Sinsabaugh RL, Zak DR (2002) The effects of long term nitrogen deposition on extracellular enzyme activity in an Acer saccharum forest soil. Soil Biol Biochem 34:1309-1315. doi:10.1016/S0038-0717(02)00074-3

SAS Institute (2010) JMP Version 9.0. SAS Institute Inc., Cary

Scurlock JMO, Hall DO (1998) The global carbon sink: a grassland perspective. Glob Change Biol 4:229-233. doi:10.1046/j.1365-2486.1998.00151.x

Shaw AN, DeForest JL (2013) The cycling of readily available phosphorus in response to elevated phosphate in acidic temperate deciduous forests. Appl Soil Ecol 63:88-93. doi:10.1016/j.apsoil.2012.09.008

Sinsabaugh RL, Follstad Shah JJ (2012) Ecoenzymatic stoichiometry and ecological theory. Annu Rev Ecol Evol System 43:313-343. doi:10.1146/annurev-ecolsys-07111 2-124414

Sinsabaugh RL, Antibus RK, Linkins AE, McClaugherty CA, Rayburn L, Repert D, Weiland T (1993) Wood decomposition: nitrogen and phosphorus dynamics in relation to extracellular enzyme activity. Ecol 74:1586-1593. doi:10. 2307/1940086

Smith BFL, Bain DC (1982) A sodium hydroxyde fusion method for the determination of total phosphate in soils. Commun Soil Sci Plant Anal 13:185-190. doi:10.1080/ 00103628209367257

Smith P, Ashmore MR, Black HIJ, Burgess PJ, Evans CD, Quine TA, Thomson AM, Hicks K, Orr HG (2013) The role of ecosystems and their management in regulating climate, and soil, water and air quality. J Appl Ecol 50:812-829. doi:10.1111/1365-2664.12016

Song B, Niu S, Li L, Zhang L, Yu G (2014) Soil carbon fractions in grasslands respond differently to various levels of nitrogen enrichments. Plant Soil 384:401-412. doi:10. 1007/s11104-014-2219-1

Sterner RW, Elser JJ (2002) Ecological Stoichiometry: the biology of elements from molecules to the biosphere. Princeton University Press, Princeton

Stursova M, Crenshaw CL, Sinsabaugh RL (2006) Microbial responses to long-term $\mathrm{N}$ deposition in a semiarid grassland. Microb Ecol 51:90-98. doi:10.1007/s00248-0055156-y

Sulman BN, Phillips RP, Oishi AC, Shevliakova E, Pacala SW (2014) Microbe-driven turnover offsets mineral-mediated storage of soil carbon under elevated CO2. Nat Clim Change 4:1099-1102. doi:10.1038/nclimate2436

Thomas DC, Zak DR, Filley TR (2012) Chronic N deposition does not apparently alter the biochemical composition of forest floor and soil organic matter. Soil Biol Biochem 54:7-13. doi:10.1016/j.soilbio.2012.05.010

Tiemann LK, Billings S (2011) Indirect effects of nitrogen amendments on organic substrate quality increase enzymatic activity driving decomposition in a mesic grassland. Ecosystems 14:234-247. doi:10.1007/s10021-010-9406-6

Trumbore SE, Gaudinski JB (2003) The secret lives of roots. Science 302:1344-1345. doi:10.1126/science.1091841

Waldrop MP, Zak DR, Sinsabaugh RL (2004) Microbial community response to nitrogen deposition in northern forest ecosystems. Soil Biol Biochem 36:1443-1451. doi:10. 1016/j.soilbio.2004.04.023

Zeglin LH, Stursova M, Sinsabaugh RL, Collins SL (2007) Microbial responses to nitrogen addition in three contrasting grassland ecosystems. Oecologia 154:349-359. doi:10.1007/s00442-007-0836-6 